\title{
"The nexus of social capital, coping ability and employment creation in African immigrant-owned small businesses"
}

\begin{tabular}{|c|c|}
\hline AUTHORS & $\begin{array}{l}\text { Eresia-Eke Chukuakadibia (D) https://orcid.org/0000-0003-4008-474X } \\
\text { Okerue Chijioke (D https://orcid.org/0000-0002-7972-6845 }\end{array}$ \\
\hline ARTICLE INFO & $\begin{array}{l}\text { Eresia-Eke Chukuakadibia and Okerue Chijioke (2018). The nexus of social } \\
\text { capital, coping ability and employment creation in African immigrant-owned small } \\
\text { businesses. Problems and Perspectives in Management, 16(3), 311-323. } \\
\text { doi:10.21511/ppm.16(3).2018.25 }\end{array}$ \\
\hline DOI & http://dx.doi.org/10.21511/ppm.16(3).2018.25 \\
\hline RELEASED ON & Wednesday, 22 August 2018 \\
\hline RECEIVED ON & Thursday, 10 May 2018 \\
\hline ACCEPTED ON & Friday, 27 July 2018 \\
\hline LICENSE & $\begin{array}{l}(c) \text { EY-NC } \\
\text { This work is licensed under a Creative Commons Attribution-NonCommercial } 4.0 \\
\text { International License }\end{array}$ \\
\hline JOURNAL & "Problems and Perspectives in Management" \\
\hline ISSN PRINT & $1727-7051$ \\
\hline ISSN ONLINE & $1810-5467$ \\
\hline PUBLISHER & LLC "Consulting Publishing Company "Business Perspectives" \\
\hline FOUNDER & LLC "Consulting Publishing Company "Business Perspectives" \\
\hline
\end{tabular}

NUMBER OF REFERENCES

79

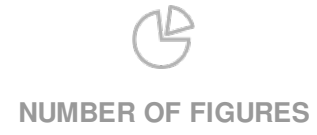

0
NUMBER OF TABLES

6

(C) The author(s) 2023. This publication is an open access article. 


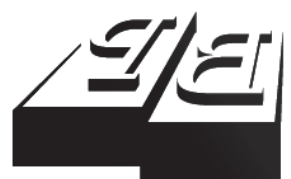

BUSINESS PERSPECTIVES

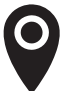

LLC "CPC "Business Perspectives" Hryhorii Skovoroda lane, 10, Sumy, 40022, Ukraine

www.businessperspectives.org

Received on: $10^{\text {th }}$ of May, 2018 Accepted on: $27^{\text {th }}$ of July, 2018

(C) Eresia-Eke Chukuakadibia, Okerue Chijioke, 2018

Eresia-Eke Chukuakadibia, Ph.D., Department of Business Management, University of Pretoria, South Africa.

Okerue Chijioke, Doctoral Candidate, Department of Business Management, University of Pretoria, South Africa.

\section{(ㄷ)(1) $(8)$}

This is an Open Access article, distributed under the terms of the Creative Commons Attribution-NonCommercial 4.0 International license, which permits re-use, distribution, and reproduction, provided the materials aren't used for commercial purposes and the original work is properly cited.
THE NEXUS OF SOCIAL

CAPITAL, COPING ABILITY AND EMPLOYMENT CREATION IN AFRICAN IMMIGRANTOWNED SMALL BUSINESSES

\begin{abstract}
Immigrant entrepreneurship, like other facets of entrepreneurship, contributes towards a country's productivity, partly through employment creation. However, the specific factors, in the form of social capital, that lend themselves to this employment creation potential, remain largely unknown. It is against this background that this study sought to determine if the variables of language proficiency and networking ability bear an association with the employment creation ability of African immigrant entrepreneurs. This quantitative study was executed from a positivism philosophical standpoint. Relying on the population of African immigrants in the small business sector in South Africa, Swaziland and Mozambique, the non-probability sampling techniques of convenience and snowball sampling were used to identify 2,500 participants. Data were collected in a cross-sectional manner, with self-administered questionnaires and an effective $33 \%$ response rate was realized.

Findings reveal a statistically significant relationship between language proficiency and employment creation, while that between networking ability and employment creation was not significant. Nonetheless, most of the studied African immigrant entrepreneurs across the countries agreed that language proficiency and networking ability have helped them cope with the rigors of operating their businesses. These findings signal the need for interventions for building language proficiency and networking ability for African immigrant entrepreneurs.
\end{abstract}

\section{Keywords}

language, networking, coping, African immigrants, entrepreneurship

\section{JEL Classification M10}

\section{INTRODUCTION}

The unemployment rate in South Africa is estimated to be at $27.7 \%$ (Statistics South Africa, 2017). These rates are arguably high and the trend seems to be the same across a number of countries in the Southern African region, as Meyer (2014, p. 67) contends that countries such as Zimbabwe, Namibia and Lesotho may even have higher unemployment rates. High rates of unemployment in any country can be a bane to its people. This is partly why in South Africa, the government has prioritized the SME sector to increase opportunities and reduce the high unemployment rate. To this end, the role for immigrant entrepreneurs who have shown to also provide jobs for locals (Kalitanyi \& Visser, 2010, p. 387) cannot be ignored, as they may be one of the useful allies that the government needs, to ensure that the high rate of unemployment in society is reduced.

Immigrants are widely perceived as being entrepreneurial and important to economic growth and innovation (Fairlie \& Lofstrom, 2015, p. 1). Accordingly, many countries have established special visas and 
entry requirements to attract immigrant entrepreneurs (Schuetze \& Antecol, 2007, p. 107). These special visa entry requirements have possibly been borne out of a belief that immigrants can contribute socio-economically and otherwise to the development of these countries. For instance, the Australian immigration policy is one of the main contributors to the job-creating activities in the country (Mahuteau, Piracha, Tani, \& Vaira Lucero, 2014, p. 62). The immigrant entrepreneurs operate in diverse areas of business, including retail, real estate, finance, media, manufacturing, and some sell ethnic products (Collins, 2008, p. 51). Evidence has shown that $90 \%$ of all immigrant entrepreneurs are small scale businesses (Azmat \& Zutshi, 2012, p. 66) and they play a major role in job creation, since about half of the work force in Australia are employed by small businesses (Collins \& Shin, 2012, p. 19).

In South Africa, the government has prioritized the SME sector to increase opportunities and reduce the high unemployment rate, which is currently estimated at 27.7\% (Statistics South Africa, 2017), however, despite the importance of the SME sector, the failure rate of SMEs in South Africa is estimated to be between $70 \%$ and $80 \%$, and this is arguably high (Fatoki, 2013, p. 209). This might also be the case with immigrant-owned businesses, as Tengeh (2013, p. 248) argues that immigrant businesses are prone to failure within the first 3 years of existence. Juxtaposed against the projection that immigrant-owned businesses can contribute meaningfully to the development of countries in which they are located, this failure rate is troubling. It is instructive to note though that despite the high rate of failure of businesses owned by immigrant entrepreneurs, studies by Rogerson (1997), Kalitanyi and Visser (2010), as well as Fatoki and Patswawairi (2012), point to the fact that immigrant entrepreneurs create jobs in South Africa for South Africans and contribute to the economic development of South Africa; a case which may not be dissimilar in neighboring countries in the South African Development Community (SADC).

While immigrant entrepreneurs have become an important variable in the socio-economic development equation of different nations (Radipere, 2012, p. 109), there are factors that continue to inhibit their performance. These factors include, stiff legal and regulatory environments, unfavorable business environments, poor access to market, inaccessibility to finance, tax burden, lack of business management skills, lack of proper education, cultural differences, rent, language challenges, crime and xenophobia (Fatoki, 2013; Basu, 2011; Tengeh, 2013), amongst others. However, despite these challenges, immigrant entrepreneurs typically remain optimistic and look towards the possibilities of expanding their business enterprises (Rogerson, 1997, p. 14).

Indeed, surviving in the perilous small business environment is technically indicative of the reality that immigrants possess the entrepreneurial quality of perseverance (Kalitanyi \& Visser, 2010, p. 382). This is unlikely to be the only attribute that immigrant entrepreneurs rely upon to surmount what Oliveria (2008) refers to as numerous obstacles that obstruct their pathway to better business performance. This is the context in which it was deemed significant to investigate variables related to social capital that possibly imbue the African immigrant entrepreneur with the ability to continue to operate a small business in selected countries in the SADC region and possibly create employment for others.

The underlying motive being that a discussion of such elements would enable African immigrant entrepreneurs and policy-makers invest more in specific variables as a necessary precursor for better performance in the cohort of small businesses that are immigrant-owned. The aims of the study are therefore:

1. To determine the extent to which African immigrant entrepreneurs consider the social capital variables of language proficiency and networking ability to be instrumental to their ability to cope with running their businesses.

2. To establish if the social capital component variables of language proficiency and networking ability on the part of African immigrant entrepreneurs correlate with employment creation in their businesses. 


\section{LITERATURE REVIEW}

Many policy-makers agree that entrepreneurs (including immigrant entrepreneurs) and the new businesses they establish play a critical role in the development and well-being of their societies (Global Entrepreneurship Monitor, 2012, p. 12). Several studies directed at the influence of entrepreneurship on economic growth confirm that entrepreneurship contributes to economic growth (Hisrich \& Brush, 2009, p. 33; Caree \& Thurik, 2003, p. 468). One of the main policy issues of any government is creating jobs and providing employment for its citizens, as employment is usually linked to the state of a country's economy. To this end, Abor and Quartey (2010, p. 223) opine that SMEs have been identified as the engine through which a nation's growth objectives can be achieved and they have the potential to create the much-needed employment for the citizens of these nations. This is because small businesses, the like of which are established by immigrant entrepreneurs, are thought to be well-positioned to contribute significantly to the provision of employment opportunities, the generation of income and eventually the reduction of poverty, which are important concerns in the Southern Africa region. Indeed, empirical studies suggest that small businesses contribute over $65 \%$ of total employment in high-income countries, over $70 \%$ of total employment in low-income countries and about 95\% of total employment in middle-income countries (Kongolo, 2010, p. 2291). In South Africa, small businesses, including those owned by immigrants, are estimated to provide about $56 \%$ of private sector employment (Fatoki \& Garwe, 2010, p. 729).

Three theoretical schools of thought have attempted to explain the emergence and growth of immigrant entrepreneurship. The first school is the theory of 'blocked opportunities' and it states that immigrant entrepreneurship is sometimes a consequence of discrimination in the host country labor markets (Sanders \& Nee, 1996, p. 232; Raijman \& Tienda, 1999, p. 6; Clark \& Drinkwater, 2000, p. 2; Basu \& Altinay, 2002, p. 3; Sahin, Nijkamp, \& Levent, 2006, p. 6; Levent, Nijkamp, \& Sahin, 2007, p. 4; Heilbrunn \& Kushnirovich, 2008, p. 693). 'Blocked opportunity' theorists argue that immigrants have access to few job opportunities and so often resort to establishing their own busi- nesses (Nee \& Sanders, 2001, p. 393) to generate much-needed income. It is important to note that the 'blocked opportunity' school of thought has been criticized for ignoring the fact that some ethnic groups may have a cultural inclination towards entrepreneurship and this may have inspired the emergence of the second school of thought (Basu \& Altinay, 2002, p. 3).

The second school of thought referred to as the 'ethnic market niche' theory advocates that immigrants are generally drawn into establishing businesses by emerging opportunities. The ethnic market niche theory is developed on the premise that immigrants find business start-up opportunities in market niches created by the society, including their own immigrant groups (Halkias, Harkiolakis, Abadir, Thurman, Akrivos, \& Caracatsanis, 2007, p. 4). Clark and Drinkwater $(2000$, p. 2) state that some of the factors that may pull immigrants into the establishment of small businesses include the existence of ethnic communities, which may provide a self-sustaining economic environment. The third school of thought referred to as the 'ethnic enclave theory' includes mainly those who are bound by ethnicity, an ethnic community's social structures and geographical location (Zhou, 2007, p. 280). The ethnic enclave theory states that immigrant entrepreneurs typically find entrepreneurial opportunities within immigrant communities (Greve \& Salaff, 2005, p. 9) and proceed to exploit them. On the basis of these three theories, immigrant entrepreneurship is likely to remain a constant feature of the economic landscape of countries, wherever immigrants are present, across the globe.

In the United States of America, immigrant entrepreneurs play a prime role in developing the economy and creating employment for the locals (Jennings, 2013, p. 2). The Fiscal Policy Institute $(2012$, p. 1) report revealed that $18 \%$ of small business owners in the United States were immigrants and this was higher than the immigrants $13 \%$ share of the population. Fairly $(2012$, p. 8$)$ found that in the United States of America, the rate at which immigrants start new businesses grew by more than 50\% between 1996 and 2011. During the same period, business formation rate for the native-born declined by $10 \%$, providing further evidence of the capacity of immigrant businesses 
to create jobs. The story is not notably different in Netherlands, where the government, having recognised the role of immigrant businesses, have developed policies aimed at promoting small businesses, especially immigrant entrepreneurship (Kloosterman, 2003, p. 168). Interestingly, due to the policy support, the number of immigrant entrepreneurs in the Netherlands increased and this helped to reduce unemployment among the immigrant population, as they were able to create employment for themselves and others (Kloosterman \& van der Leun, 1999, p. 665). Immigrant entrepreneurs have also contributed to the economy of Australia by creating employment and enabling the growth of certain sectors (Kloosterman \& Rath, 2002, p. 27) in which they participate.

Southern Africa has a long history of intra-regional migration, which dates back to the mid nineteenth century. Migration was probably the single most important factor that tied together all of the various colonies and countries of the sub-continent into a single regional labor market during the twentieth century (Crush, Williams, \& Perbedy, 2005 , p. 1). It is perhaps in keeping with this trend that more African immigrants are beginning to find residence in the region. However, unlike the temporary workers who came to work in the mines and agricultural sectors, less is known about migrants who come from places with established informal and small business economy experience (Timberg, 2005, p. 4), like those from other regions in Africa.

The part that such immigrant entrepreneurs can play in entrepreneurship development and job creation in the SADC region may be crucial given the findings of the 2015 Global Entrepreneurship Monitor (GEM) report. While Mozambique and Swaziland have not participated in GEM studies, South Africa, on the other hand, has been a constant participant and its TEA rates have been 7.3\% in $2012,10.6 \%$ in 2013 and $7.0 \%$ in 2014 . These figures suggest that the TEA rate in South Africa decreased by 34\% between 2013 and 2014, indicative of the fact that South Africa is regressing when compared with some other African countries (Global Entrepreneurship Monitor, 2014, p. 22). Against this backdrop, immigrant entrepreneurs from other parts of the African continent with higher levels of TEA might become important var- iables in the overall equation for job creation and increased TEA in South Africa, as well as the entire SADC region. Undoubtedly, much of this will be dependent on the emergence and performance of the African-owned immigrant businesses.

Instructively, the performance of a new entrepreneurial venture is not only determined by the founders' talent and good luck, but also, among others, by the social capital invested in the venture (Bosma, van Praag, Thurik, \& de Wit, 2004, p. 228). Cleary, a mixture of capitals, of which social capital is an important component, is critical for business prosecution (Mandviwalla \& Watson, 2014, p. 98). In an investigation of the determinants of successful entrepreneurship, Bosma, Acs, Autio, Coduras, and Levie (2009, p. 10) identified the social capital variable as being influential to the success of businesses. This is the case, as, according to Kamitewoko (2013, p. 114), social capital is important for retrieving relevant information for running and sustaining the business.

The social capital concept has, unfortunately, been complicated by the existence of multifaceted abstract definitions, differing theoretical perspectives and inconsistent operationalization (Payne, Moore, Griffis, \& Autry, 2011, p. 492). Generally, it seems that the concept of social capital cannot empirically be differentiated in terms of resources and the nature of the relationships that make up the resources, which likely exist, because social capital is not open to independent measurement (Gedajlovic, Honig, Moore, Payne, \& Wright, 2013, p. 459). Lin (1999, p. 30) defines social capital as investment in social relations with expected returns in the market place, while insisting that social capital is created through social relationships and the expectations of the future social resources they can generate. Nahapiet and Ghoshal $(1998$, p. 243$)$ view social capital as the sum of actual and potential resources embedded within, available through and derived from the network of relationships possessed by an individual or a social unit. Social capital relationships understood to be goodwill can therefore be organized to create resources, which enable action (Adler \& Kwon, 2002, p. 17).

In the specific case of immigrants, they normally draw on ethnic resources, which include solidarity, social networks and social capital (Light 
\& Rosenstein, 1995, p. 25). This is because social capital is strongest when one is entrenched within a particular community (Uzzi, 1997, p. 37). The immigrants' social capital mainly originates from goodwill within their community, which then influences the flow of information, helps to strengthen relationships and provides an important avenue for vital resource acquisition (Ndofor \& Prien, 2011, p. 795). Social networks typically serve as the medium through which individuals generate social capital and once accumulated, it can be used when the need arises (Boisjoly, Duncan, \& Hofferth, 1995, p. 609). A social network could therefore be a vital resource for the immigrant entrepreneur.

However, it is worthy to note that there is no consensus, as it relates to the contribution of social capital to business performance, especially employment growth in immigrant-owned small businesses. In fact, Locke (1999, p. 8) argues that social capital does not promote entrepreneurship, because it reduces knowledge and objectivity. Similarly, Aldrich, and Kim (2007, p. 160) aver that it imposes mental conformity on whole groups, which could possibly affect business venturing. More so, social capital can suppress entrepreneurship when a dominant group excludes subordinates from reciprocal advantages that it enjoys (Crow, 2004, p. 12). A converse position is evident from studies in Australia (Giorgas, 2000) and in the USA (Amuedo-Dorantes \& Mundra, 2004), which found that social capital has a significant effect on the economic performance of immigrant-owned businesses, especially in the initial years. These contrasting positions make it unclear when social capital is a catalyst, an obstacle and when it is not a part of entrepreneurship (Light \& Dana, 2013, p. 604).

Besides the issue of networking, Bolino, Turnley, and Bloodgood (2002, p. 511) insist that social capital also includes ability to use a common language and the possession of shared narratives. It is their belief that proficiency in a local common language will help businesses and employees develop and understand common myths and stories, which could possibly enable business survival. This position may or may not be the case with African immigrant entrepreneurs in the SADC region due to contextual nuances associ- ated with studies of this nature and this is partly what has motivated this study. The motivation is fanned by the declaration of Turkina and Thai (2013, p. 111) that there is a limited knowledge of social capital at the entrepreneurship level across countries and more importantly, that the effects of social capital on immigrant entrepreneurship have been largely under-explored in literature. Consequently, rather than explore all possible variables that may fall within the social capital construct, the study elects to focus specifically on the elements of language proficiency (LP) and networking ability (NA) as its independent variables, while employment creation (EC) is considered as the dependent variable.

\subsection{Language proficiency}

Hisrich (2010, p. 46) states that language, sometimes considered as the mirror of culture, is composed of verbal and non-verbal components. Messages and ideas are conveyed by spoken words embellished by the voice tone and non-verbalactions like body positioning, eye contacts and gestures. To conduct any business in a certain area, the immigrant might require a relatively good understanding of the language used in doing business. So, the immigrant entrepreneur or someone working for the immigrant should have a good command of the local language (Khosa \& Kalitanyi, 2014, p. 208).

Like in most African countries, Mozambique is a multilingual and multicultural country. Portuguese may be the official language, however, there are other languages spoken in Mozambique, which belong to the Bantu language group. They are indigenous languages and constitute the major language stratum, both with regard to number of speakers and in terms of language distribution (Lopes, 1998, p. 441). The post-apartheid constitution of South Africa officially recognizes eleven languages (nine local African languages, English and Afrikaans), however, English appears to be the popular language of economic exchange and therefore the language of access and power (Setati \& Adler, 2000, p. 247). While Swaziland has two official languages (Siswati and English), English tends to be associated with employment opportunities, as it is also the language of government and administration (Kamwangamalu, 2013, p. 162). 
This may therefore suggest that immigrants who speak English may find it easier to adapt to the business environment in both South Africa and Swaziland, but may be disadvantaged in Mozambique, since they may have to learn the official language, which is Portuguese. Even when the immigrant is proficient in the official language, learning and speaking a popular local language could also give the immigrant entrepreneur an important advantage in business transactions, culminating in levels of performance that inevitably create employment for others. While recognizing this trail of thought, this study elects to hypothesize in the null form that:

$H_{01}: \quad$ There is no relationship between the African immigrant entrepreneur's local language proficiency and employment creation in the business.

\subsection{Networking}

Networking is the process of meeting people, building relationships that can benefit all those involved, sharing information and ideas and getting one's business on the map (Burke \& Segaloe, 2003 , p. 7). Spenelli and Adams (2012, p. 148) opine that networks can be a stimulant and source of new ideas, as well as a source of valuable contact with people. This may suggest that a network with people of similar experiences could help to encourage the immigrant entrepreneur. In agreement, Johannisson (1990, p. 41) argues that the personal network of entrepreneurs is the most strategically significant resource available to them and could therefore play an important role in their businesses.

To emphasize the usefulness of networks, Sequeira and Rasheed (2006, p. 361) found that immigrant entrepreneurs acquire resources from two major sources, which are own families and social networks in their ethnic enclaves. Fatoki and Oni $(2014$, p. 287$)$ support this finding by alluding to the fact that in the respondent population for their study, none of the new immigrant entrepreneurs interviewed was able to obtain resources from the official networks. The prevalent trend was that resources were obtained through social networks, friends, relatives and family. However, they were able to get resources from the business/manage- rial networks (suppliers, business associations) at a later stage or at a more established stage of their businesses. This discussion seems to fertilize the idea that networking ability can enable rather than disable business performance that translates into the creation of employment opportunities. Nonetheless, this study's null hypothesis is that:

\section{$H_{02}: \quad$ There is no relationship between the African immigrant entrepreneur's networking ability and employment creation in the business.}

\section{RESEARCH METHODOLOGY}

This study followed a research design strategy that commenced with the exploration of extant literature as a necessary prelude for the conduct of the formal study. This is in line with the thoughts of Cooper and Schindler (2011, p. 140) to the effect that the formal study begins at the terminal point of the exploration effort and often starts with the hypotheses or research questions, while adhering to specific scientific processes and data requirements.

This research is a cross-country study and covers six cities in three countries in the SADC region. The target population therefore comprises African immigrant entrepreneurs with businesses in the small business sector in Johannesburg or Pretoria (South Africa), Manzini or Mbabane (Swaziland) and Maputo or Boane (Mozambique). These cities have been selected, because they are arguably commercial centers in their respective countries.

Unfortunately, there was no compendium of African immigrant entrepreneurs in the selected cities, but the researchers project that more than 5,000 African immigrant entrepreneurs may be found in these cities. According to Leedy and Ormrod (2005, p. 207), if the population size goes beyond 5,000, a sample size of approximately 400 respondents could be deemed as adequate. The non-probability sampling techniques of convenience sampling and snowballing were utilized to identify and select potential study respondents.

Primary data were collected in a cross-sectional manner for the study with the use of self-admin- 
Table 1. Gender profile of respondents

\begin{tabular}{|c|c|c|c|}
\hline \multirow{2}{*}{\multicolumn{2}{|c|}{ Sample descriptives }} & \multicolumn{2}{|c|}{ Gender } \\
\hline & & \multirow{2}{*}{$\frac{\text { Male }}{520}$} & \multirow{2}{*}{$\frac{\text { Female }}{309}$} \\
\hline & $n$ & & \\
\hline Iotal sample & $\%$ & $62.7 \%$ & $37.3 \%$ \\
\hline \multirow{3}{*}{ Country } & South Africa (313) & $55.0 \%$ & $45.0 \%$ \\
\hline & Swaziland (218) & $55.0 \%$ & $45.0 \%$ \\
\hline & Mozambique (298) & $76.5 \%$ & $23.5 \%$ \\
\hline \multirow{4}{*}{ Grouped age } & $18-29$ & $55.5 \%$ & $44.5 \%$ \\
\hline & $30-39$ & $60.3 \%$ & $39.8 \%$ \\
\hline & $40-49$ & $72.6 \%$ & $27.4 \%$ \\
\hline & $50+$ & $73.2 \%$ & $26.8 \%$ \\
\hline \multirow{7}{*}{$\begin{array}{l}\text { Highest level of } \\
\text { formal education }\end{array}$} & Sub-matriculation education & $65.5 \%$ & $34.5 \%$ \\
\hline & Secondary school: matriculation certificate & $68.9 \%$ & $31.1 \%$ \\
\hline & Vocational education: diploma & $57.4 \%$ & $42.6 \%$ \\
\hline & Vocational education: certificate & $37.7 \%$ & $62.3 \%$ \\
\hline & Vocational education: artisan qualification & $76.7 \%$ & $23.3 \%$ \\
\hline & University education: degree & $61.9 \%$ & $38.1 \%$ \\
\hline & University education: postgrad qualification & $66.0 \%$ & $34.0 \%$ \\
\hline
\end{tabular}

istered questionnaires. The questionnaire was predominantly made up of five-point Likert scale items with measures ranging from 'strongly disagree' to 'strongly agree'. In all, a total of 2,500 questionnaires were distributed and 976 questionnaires were returned, which is indicative of a $39 \%$ response rate. However, for purposes of statistical analysis, a conscious decision was made to exclude questionnaires with missing values or data errors.

Due to this, 147 questionnaires were eliminated, leaving a total of 829 valid questionnaires. This translates to an effective response rate of $33 \%$. This can be considered to be acceptable for studies of this nature based on the position of Curran and Blackburn (2001) that small business research is typically characterized by low response rates. Besides, the study's effective response rate mirrors the $33.3 \%$ response rate achieved by Watt, Simpson, Mckillop, and Nunn (2002) in a similar study.

As a precursor for statistical analysis, it was necessary to evaluate the measurement scale for the variables of interest contained in the questionnaire. The effort culminated in the elimination of some questionnaire items that had low factor loadings. Seven of the sixteen items related to language proficiency, networking ability and employment creation had factor loadings lower than 0.5 and were therefore excluded from further statistical analysis.

\section{RESULTS}

The demographic profiles of the respondents reflect the extent of diversity of the immigrant entrepreneurs who participated in the study. The profile covers the countries from where the respondents were drawn, the respondents' gender, their grouped ages and their level of education. The distribution for gender by country, grouped age and highest level of education is presented in Table 1 . The result shows that $62.7 \%$ of the respondents were male and $37.3 \%$ female. Differences in the distribution by country are evident.

The total respondents from South Africa were 313 , of which $55 \%$ were male. Swaziland recorded 218 respondents in total, of which 55\% were male. There were 298 respondents from Mozambique and $76.5 \%$ of them were male. The results show that more male immigrant entrepreneurs responded across countries, but Mozambique at $76.5 \%$ recorded a relatively higher percentage of male respondents. Indeed, across all the dimensions considered, males repeatedly achieved higher percentages as compared to females, except for the dimension of proportion of immigrant entrepreneurs with vocational education culminating in a certificate. Along this dimension, the percentage of females was $62.3 \%$, while that associated with their male counterparts was $37.7 \%$. 
Table 2. Age groups

\begin{tabular}{|c|c|c|c|c|c|}
\hline \multirow{2}{*}{\multicolumn{2}{|c|}{ Sample descriptives }} & \multicolumn{4}{|c|}{ Age groups } \\
\hline & & \multirow{2}{*}{$\frac{\mathbf{1 8 - 2 9}}{191}$} & \multirow{2}{*}{$\frac{\text { 30-39 }}{400}$} & \multirow{2}{*}{$\frac{\mathbf{4 0 - 4 9}}{197}$} & \multirow{2}{*}{$\begin{array}{c}\mathbf{5 0 +} \\
41\end{array}$} \\
\hline Totol comolo & $n$ & & & & \\
\hline rotal sample & $\%$ & $23.0 \%$ & $49.3 \%$ & $23.8 \%$ & $4.9 \%$ \\
\hline \multirow{3}{*}{ Country } & South Africa (313) & $29.1 \%$ & $47.6 \%$ & $19.1 \%$ & $4.2 \%$ \\
\hline & Swaziland (218) & $35.3 \%$ & $42.2 \%$ & $18.3 \%$ & $4.1 \%$ \\
\hline & Mozambique (298) & $7.7 \%$ & $53.4 \%$ & $32.6 \%$ & $6.4 \%$ \\
\hline \multirow{2}{*}{ Gender } & Male & $20.4 \%$ & $46.3 \%$ & $27.5 \%$ & $5.8 \%$ \\
\hline & Female & $27.5 \%$ & $51.5 \%$ & $17.5 \%$ & $3.6 \%$ \\
\hline \multirow{7}{*}{$\begin{array}{l}\text { Highest level of } \\
\text { formal education }\end{array}$} & Sub-matriculation education & $41.4 \%$ & $46.0 \%$ & $8.0 \%$ & $4.6 \%$ \\
\hline & Secondary school: matriculation certificate & $26.5 \%$ & $53.3 \%$ & $16.7 \%$ & $3.5 \%$ \\
\hline & Vocational education: diploma & $22.5 \%$ & $48.8 \%$ & $25.6 \%$ & $3.1 \%$ \\
\hline & Vocational education: certificate & $23.2 \%$ & $47.8 \%$ & $26.1 \%$ & $2.9 \%$ \\
\hline & Vocational education: artisan qualification & $20.9 \%$ & $34.9 \%$ & $37.2 \%$ & $7.0 \%$ \\
\hline & University education: degree & $14.2 \%$ & $47.2 \%$ & $31.0 \%$ & $7.7 \%$ \\
\hline & University education: postgrad qualification & $10.6 \%$ & $40.4 \%$ & $40.4 \%$ & $8.5 \%$ \\
\hline
\end{tabular}

The distribution for age groups by country, gender and highest level of education is presented in Table 2 . The data show a higher number of immigrant entrepreneurs within the age group of 30-39 years. This finding is in line with the age distribution of early entrepreneurial activity that, according to GEM (2015, p. 26), takes place among individuals in the age bracket of 25-44 years. This age group is considered to be in their early and mid-career stages.

Indeed, a total of 400 immigrant entrepreneurs belonged to the 30-39 years age bracket. Of the 313 immigrant entrepreneurs in South Africa, $47.6 \%$ were from this group, $42.2 \%$ of the 218 respondents from Swaziland were from the same group and $53.4 \%$ of 298 immigrant entrepreneurs who responded in Mozambique also belong to the same group. The results also showed that the grouped age of 30-39 had more female immigrant entrepreneurs at $51.5 \%$, while the balance of $46.3 \%$ were males. The predominance of 30-39 year old African immigrant entrepreneurs operating in the SADC region is further emphasized by the fact that the group consistently reflects the highest percentages across all dimensions considered in Table 2.

Table 3 reports descriptive statistics based on the respondents' actual reported age per country. For the total sample, an average age of 35.6 years $(\mathrm{SD}=7.94)$ is reported. The minimum age reported is 18 years and the maximum age 75 years. The median age of respondents corresponded with the average age. The mean ages for the countries are 34.5 years $(\mathrm{SD}=7.78)$ for South Africa, 33.9 years $(\mathrm{SD}=8.36)$ for Swaziland and 38.1 years $(\mathrm{SD}=7.20)$ for Mozambique. These figures reveal that hardly any difference exists between the mean ages of African immigrant entrepreneurs operating in South Africa and Swaziland. The mean age for those operating in Mozambique is, however, relatively higher.

The study sought to determine the perceptions of the studied immigrants, as it concerns the issue of whether the social capital variables of interest helped them cope with running their businesses.

Table 3. Descriptive statistics for age by country

\begin{tabular}{|c|c|c|c|c|}
\hline \multirow{2}{*}{ Statistical measures } & \multicolumn{3}{|c|}{ Country } & \multirow{2}{*}{ Total sample } \\
\hline & South Africa & Swaziland & Mozambique & \\
\hline Mean & 34.5 & 33.9 & 38.1 & 35.6 \\
\hline Median & 34.0 & 31.0 & 38.0 & 35.0 \\
\hline Standard deviation & 7.78 & 8.36 & 7.20 & 7.94 \\
\hline Minimum & 22 & 18 & 20 & 18 \\
\hline Maximum & 71 & 75 & 70 & 75 \\
\hline Valid n & 313 & 218 & 298 & 829 \\
\hline
\end{tabular}


Table 4. Country-specific ANOVA results for the variables of language proficiency (LP) and Networking ability (NA)

\begin{tabular}{|c|c|c|c|c|c|c|}
\hline Variables & Country & $\mathbf{N}$ & Mean & SD & $F(d f)$ & p-value \\
\hline \multirow{3}{*}{ Language proficiency (LP) } & South Africa & 313 & 3.87 & 0.710 & \multirow{3}{*}{$\begin{array}{l}386.115 \\
(2 ; 826)\end{array}$} & \multirow{3}{*}{0.000} \\
\hline & Swaziland & 218 & 4.35 & 0.630 & & \\
\hline & Mozambique & 298 & 4.12 & 0.537 & & \\
\hline \multirow{3}{*}{ Networking ability (NA) } & South Africa & 313 & 4.05 & 0.508 & \multirow{3}{*}{$\begin{array}{c}20.793 \\
(2 ; 826)\end{array}$} & \multirow{3}{*}{0.000} \\
\hline & Swaziland & 218 & 4.31 & 0.536 & & \\
\hline & Mozambique & 298 & 4.04 & 0.512 & & \\
\hline
\end{tabular}

The analysis of variance (ANOVA) was employed as the statistical tool for the investigation. The results of the analysis are shown in Table 4.

All the means for the independent variables of LP and NA were above 4, except the LP mean score for immigrant entrepreneurs in South Africa, which was 3.87. The results indicate that immigrant entrepreneurs across countries, to a large extent, agree that the variables independent variables of LP and NA are instrumental to their ability to cope with their business.

The Tukey HSD test, as depicted in Table 5, shows that significant differences are evident across countries for the LP variable, as the results indicate that the perceptions of immigrant entrepreneurs on the importance of language in aiding their ability to cope with their businesses differ when compared across countries. The results are similar for the NA variable, except for the case of perceptions of immigrant entrepreneurs in Mozambique and South Africa where no statistical difference was evident judging by the value of
0.916 realized with the Tukey HSD test.

Part of the aim of the study was also to investigate if the hypothesized relationships between employment creation and the social capital elements of language proficiency and networking have any statistical basis. The regression analysis results are presented in Table 6.

Table 6. Results of analysis of relationship between independent and dependent variables

\begin{tabular}{ll|l}
\hline & \multicolumn{1}{c}{ Hypotheses } & Results \\
\hline $\mathrm{H}_{01}$ & $\begin{array}{l}\text { There is no relationship between the } \\
\text { African immigrant entrepreneur's } \\
\text { local language proficiency and } \\
\text { employment creation in the busines }\end{array}$ & $\mathrm{p}=0.015$ \\
$\mathrm{H}$ & $\begin{array}{l}\text { There is no relationship between the } \\
\text { African immigrant entrepreneur's } \\
\text { networking ability and employment } \\
\text { creation in the business }\end{array}$ & $\mathrm{p}_{02}=0.379$ \\
$\mathrm{H}_{02}$ & $\mathrm{H}_{02}$ is accepted \\
\hline
\end{tabular}

At a 95\% confidence level, the regression analysis results show the existence of a statistically significant relationship $(r=-0.47, p=0.015)$ between language proficiency and employment creation in immigrant-owned businesses. A study by Gebre,

Table 5. Post-hoc tests for cross-country perceptions of the contributing roles of LP and NA to the coping ability of African immigrant entrepreneurs

\begin{tabular}{|c|c|c|c|}
\hline Variables & \multicolumn{2}{|c|}{ Countries } & Sig. \\
\hline \multirow{7}{*}{$\mathrm{LP}$} & \multirow{2}{*}{ South Africa } & Swaziland & 0.000 \\
\hline & & Mozambique & 0.000 \\
\hline & \multirow{2}{*}{ Swaziland } & South Africa & 0.000 \\
\hline & & Mozambique & 0.000 \\
\hline & \multirow{3}{*}{ Mozambique } & South Africa & 0.000 \\
\hline & & Swaziland & 0.000 \\
\hline & & Swaziland & 0.000 \\
\hline \multirow{6}{*}{$\mathrm{NA}$} & \multirow{2}{*}{ South Africa } & Swaziland & 0.000 \\
\hline & & Mozambique & 0.916 \\
\hline & \multirow{2}{*}{ Swaziland } & South Africa & 0.000 \\
\hline & & Mozambique & 0.000 \\
\hline & \multirow{2}{*}{ Mozambique } & South Africa & 0.916 \\
\hline & & Swaziland & 0.000 \\
\hline
\end{tabular}


Maharaj, and Pillay (2011, p. 31) of immigrant entrepreneurs in South Africa revealed that the inability of some immigrants to speak English or any other local language has compelled them to live a segregated life, which may have some ramifications for their business. This is more so for immigrants that arrive from countries, where English language is not the official language. Curiously, while proficiency in the local language may be associated with employment creation, the relationship is actually a moderate and inverse one.

Networking ability did not show any statistically significant relationship $(r=0.22, p=0.232)$ with employment creation in immigrant-owned businesses and so hypothesis $H_{02}$ was accepted. This result is not necessarily in harmony with the findings of the studies undertaken by Johannisson (1990, p. 41), as well as Fatoki and Oni (2014, p. 284), who opine that the personal networks of entrepreneurs are the most strategically useful resources available to them. Immigrant entrepreneurs need information, capital, skills and labor for business operations and it is sometimes necessary to complement these resources with others that are accessed through their contacts. While acknowledging their position, this study asserts that the networking ability of the African immigrant entrepreneur may enable ease of access to other resources, but it does not correlate with employment creation in the immigrant-owned small business.

\section{CONCLUSION}

The study shows that the average age of the studied immigrant entrepreneurs in South Africa, Mozambique and Swaziland is in line with the position of GEM (2015). Males also seem to predominate the immigrant entrepreneurship sector, possibly due to the patriarchal nature of the African society. The disparity in gender representation in the immigrant entrepreneurship pool of this study for Swaziland and South Africa (55\% for male; $45 \%$ for female) appear small relative to that of Mozambique ( $76.5 \%$ for male; $23.5 \%$ for female). There is therefore a need to encourage more female immigrants to venture into the small business terrain across the SADC region, but even more urgently so, in Mozambique.

There were statistically significant cross-country differences in the perceptions of the studied African immigrant entrepreneurs, as it relates to the instrumental role of language proficiency and networking ability to their ability to cope with their businesses. The mean scores obtained across the countries, however, reflect the fact that most respondents agreed that an African immigrant entrepreneur's coping ability would benefit from language proficiency and networking ability. This clearly demonstrates the premium placed by the respondents on these two variables in the social capital construct.

The study findings show that LP rather than NA is related to employment creation in the immigrant-owned small business. In the business world, communication is important to the success of any business. In the SADC region, different languages apart from the official languages are spoken. In South Africa, for instance, the situation is complicated by the fact that the country has eleven official languages. Even in Mozambique, where the Portuguese language is predominant, other local languages are commonly used. The situation is hardly different for Swaziland, despite the prominence of SiSwati. The collage of languages often spoken in these three countries obviously has some implications for the findings of this study. This is because the study shows that the local language proficiency of the immigrant entrepreneur does not positively correlate with the employment creation potential of the immigrant-owned business. This may be because of the plethora of languages in the region, which implies that the customers of the business of the African immigrant entrepreneur may not necessary speak the same language and so the entrepreneur may only enjoy some edge if he/she is a polyglot. Besides, in the absence of local language proficiency, immigrant entrepreneurs tend to employ people who can speak the local languages in order to facilitate business transactions with locals. This in itself amounts to the creation of employment. In cases where the immigrant entrepreneur becomes well-versed in the local languages, the need to employ locals becomes substantially eroded. 
This study contributes to the body of knowledge in the field of entrepreneurship and adds to the on-going research about immigrant entrepreneurs. This study's contribution is noteworthy, given that it used a cross-country survey approach for the gathering of data on African immigrant entrepreneurs and so it was able to provide more insight about selected variables, while engendering ease of comparison of aggregate positions across the studied countries in the SADC region. This research has also demonstrated that local language proficiency contributes to the coping ability of immigrant entrepreneurs, but it does not necessarily relate, albeit, directly with employment creation. Consequently, organizations that are interested in developing immigrant entrepreneurship for the central purpose of employment creation may not need to occupy themselves with local language learning interventions, specifically, targeting the cohort of immigrant entrepreneurs.

\section{REFERENCES}

1. Abor, J., \& Quartey, P. (2010). Issues in SME development in Ghana and South Africa. International Research Journal of Finance and Economics, 39(6), 215-228. Retrieved from https:// www.researchgate.net/publication/270758190_Issues_in_SME_ Development_in_Ghana_and_ South_Africa

2. Adler, P., \& Kwon, S. (2002). Social capital: Prospects for a new concept. Academy of Management Review, 27(1), 17-40. https://doi. org/10.2307/4134367

3. Aldrich, H., \& Kim, P. (2007). Small worlds, infinite possibilities? How social networks affect entrepreneurial team formation and search. Strategic Entrepreneurship Journal, 1(1-2), 147-165. https://doi. org/10.1002/sej.8

4. Amuedo-Dorantes, C., \& Mundra, K. (2004). Social networks and their impact on the employment and earnings of mexican immigrants (Paper provided by EconWPA in its series Labor and Demography with 0502001).

5. Azmat, F., \& Zutshi, A. (2012). Perceptions of corporate social responsibility amongst immigrant entrepreneurs. Social Responsibility Journal, 8(1), 63-76. https://doi. org/10.1108/17471111211196575

6. Basu, A. (2011). From "break out" to "breakthrough": Successful market strategies of immigrant entrepreneurs in the UK. International Journal of Entrepreneurship, 15, 1-23.
7. Basu, A., \& Altinay, E. (2002). The interaction between culture and entrepreneurship in London's immigrant businesses. International Small Business Journal, 20(4), 371-394.

8. Boisjoly, J., Duncan, G., \& Hofferth, S. (1995). Access to social capital. Journal of Family Issues, 16(5), 609-631. https://doi. org/10.1177/019251395016005006

9. Bolino, M., Turnley, W., \& Bloodgood, J. (2002). Citizenship behavior and the creation of social capital in organisations. Academy of Management Review, 27(4), 505-522.

10. Bosma, N., Van Praag, M., Thurik, R., \& De Wit G. (2004). The Value of Human and Social Capital Investments for the Business Performance of Startups. Small Business Economics, 23(1), 227-236.

11. Bosma, N., Acs, Z.J., Autio, E., Coduras, A., \& Levie, J. (2009). Global Entrepreneurship Monitor: 2008 Executive Report. Global Entrepreneurship Monitor.

12. Burke, M., \& Segaloe, I. (2003). Umsobomvu Youth Fund. Networking Your Way to Success: A Guide. Self-employment series. Retrieved from: www.youthportal. org.za (accessed on July 23, 2017).

13. Carree, M., \& Thurik, A. (2003). The impact of entrepreneurship on economic growth. In Handbook of entrepreneurship research (pp. 437471). Springer US.

14. Clark, K., \& Drinkwater, S. (2010). Recent trends in minority ethnic entrepreneurship in Britain.
International Small Business Journal, 28(2), 136-146.

15. Collins, J. (2008). Immigrant entrepreneurs in Australia: regulations and responses. Migracoes: Journal of the Portugal Immigration Observatory, 3, 49-59.

16. Collins, J., \& Shin, J. (2012). Korean Immigrant Entrepreneurs in the Sydney Restaurant Industry. Sydney, UTS Cosmopolitan Civil Societies Research Centre.

17. Cooper, D., \& Schindler P. (2011). Business Research Methods (11th ed.). McGraw - Hill International Edition.

18. Crow, G. (2004). Social networks and social exclusion: An overview of the debate. In C. Phillipson, G. Allan \& D. Morgan (Eds.), Social Networks and Social Exclusion, Sociological and Policy perspectives (pp. 7-19). Aldershot, U.K.: Ashgate.

19. Crush, J., Williams, V., \& Peberdy, S. (2005). Migration in southern Africa. Paper prepared for the Policy Analysis and Research Programme of the Global Commission on International Migration.

20. Curran, J., \& Blackburn, R. (2001). Researching the small enterprise. London: Sage publications.

21. Fairlie, R., \& Lofstrom, M. (2015). Immigration and entrepreneurship. In B. R. Chiswick \& P. W. Miller (Eds.), Handbook on the Economics of International Migration. Elsevier: North Holland.

22. Fairly, R. (2012). Open for business: how immigrants are driving small 
business creation in the United States. New York: Partnership for a new American economy.

23. Fatoki, O., \& Garwe, D. (2010). Obstacles to the Growth of New SMEs in South Africa: A Principal Component Analysis Approach. African Journal of Business Management, 4(5), 729-738.

24. Fatoki, O., \& Patwawairi, T. (2012). The motivations and obstacles to immigrant entrepreneurship in South Africa. Journal of Social Science, 32(2), 133-142.

25. Fatoki, O. (2013). The determinants of immigrant entrepreneurs' growth expectations in South Africa. Journal of Social Science, 37(3), 209-216.

26. Fatoki, O., \& Oni, O. (2014). The Networking Behaviour of Immigrant Entrepreneurs in South Africa. Mediterranean Journal of Social Sciences, 5(20), 284-290.

27. Fiscal Policy Institute (2012) Immigrant Small Business Owners. A Significant and Growing Part of the Economy. A Report from the Fiscal Policy Institute's Immigration Research Initiative. Retrieved from http://www.fiscalpolicy.org (accessed on April 5, 2014).

28. Gebre, L., Maharaj, P., \& Pillay, N. (2011). The Experiences of Immigrants in South Africa: A Case Study of Ethiopians in Durban, South Africa. Urban Forum, 22(1), 23-35.

29. Gedajlovic, E., Honig, B., Moore, C., Payne, G., \& Wright, M. (2013). Social capital and entrepreneurship: A schema and research agenda. Entrepreneurship Theory and Practice, 37(3), 455-478.

30. Giorgas, D. (2000, July). Community formation and social capital in Australia. Paper presented at 7th Australian Institute of Family Studies Conference, Sydney (25).

31. Global Entrepreneurship Monitor (2012). South African report. Cape Town: University of Cape Town Graduate School of Business, University of Cape Town.
32. Global Entrepreneurship Monitor (2014). South African report. Cape Town: University of Cape Town Graduate School of Business, University of Cape Town.

33. Global Entrepreneurship Monitor (2015). South African report. Cape Town: University of Cape Town Graduate School of Business, University of Cape Town.

34. Greve, A., \& Salaff, J. (2005). Social Network Approach to Understand the Ethnic Economy: A Theoretical Discourse. GeoJournal, 64(1), 7-16.

35. Halkias, D., Harkiolakis, N., Abadir, S., Thurman, P., Akrivos, D., \& Caracatsanis, S. (2007). Characteristics and business profiles of immigrant-owned small firms: the case of Albanian immigrant entrepreneurs in Greece. International Journal of Business Innovation and Research, 3(4), 382-401.

36. Heilbrunn, S., \& Kushnirovich, N. (2008). The impact of policy on immigrant entrepreneurship and businesses practice in Israel. International Journal of Public Sector Management, 21(7), 693-703.

37. Hisrich, R. (2010). International Entrepreneurship. London: Sage Publications.

38. Hisrich, R., \& Brush, C. (2009). The woman entrepreneur: Management skills and business problems. Journal of Small Business Management, 22(1), 30-37. Retrieved from https:// digitalknowledge.babson.edu/ eshppw/27/

39. Jennings, J. (2013). Immigrant Entrepreneurs: Creating Jobs and Strengthening the US Economy in Growing Industries: Transportation, Food and Building Services: with a Regional View of Massachusetts, New York and Pennsylvania and a Focus on the Green Economy. Immigrant Learning Center.

40. Johannisson, B. (1990). Economies of overview - guiding the external growth of small firms. International Small Business Journal, 9(1), 32-44.

41. Kalitanyi, V., \& Visser, K. (2010). African immigrants in
South Africa: jobs takers or job creators? South African Journal of Economics and Management Science, 13(4), 376-390.

42. Kamitewoko, E. (2013). Determinants of entrepreneurship success: An examination of Chinese-owned businesses in Congo Brazzaville. Chinese Studies, 2(3), 113-120

43. Kamwangamalu, N. (2013). Language-in-education policy and planning in Africa's monolingual kingdoms of Lesotho and Swaziland. Language policies in education: critical issues, 156-169.

44. Khosa, R., \& Kalitanyi, V. (2014). Challenges in Operating MicroEnterprises by African-Foreign Entrepreneures in Cape Town South Africa. Mediterranean Journal of Social Sciences, 5(10), 205-215.

45. Kloosterman, R., \& Rath, J. (2002). Working on the fringes. Immigrant businesses, economic integration and informal practices. In Marginalisering eller Integration (pp. 27-38). NUTEK, Stockholm.

46. Kloosterman, R., \& Van Der Leun, J. (1999). Just for starters: commercial gentrification by immigrant entrepreneurs in Amsterdam and Rotterdam neighbourhoods. Housing Studies, 14(5), 659-677.

47. Kloosterman, R. (2003). Creating opportunities. Policies aimed at increasing openings for immigrant entrepreneurs in the Netherlands. Entrepreneurship \& Regional Development, 15(2), 167-181.

48. Kongolo, M. (2010). Job creation versus job shedding and the role of SMEs in economic development. African Journal Business Management, 4(11), 2288-2299.

49. Leedy, P., \& Ormrod, J. (2005). Practical Research: Planning and Design (8th ed.). Upper Saddle River: Pearson.

50. Levent, B., Nijkamp, P., \& Sahin, M. (2007). New orientations in ethnic entrepreneurship motivation, goals and strategies of new generation ethnic 
immigrants. Paper presented at the $7^{\text {th }}$ International Conference on Diversity in Organisations, Communities and Nations.

51. Light, I., \& Dana, L. (2013). Boundaries of social capital in entrepreneurship. Entrepreneurship Theory and Practice, 37(3), 603-624.

52. Light, I., \& Rosenstein, C. (1995). Race, ethnicity, and entrepreneurship in urban America. Transaction Publishers.

53. Lin, N. (1999). Building a network theory of social capital. Connections, 22(1), 28-51.

54. Locke, E. (1999). Some reservations about social capital. The Academy of Management Review, 24(1), 8-9.

55. Lopes, A. (1998). The language situation in Mozambique. Journal of Multilingual and Multicultural Development, 19(5), 440-486.

56. Mahuteau, S., Piracha, M., Tani, M., \& Vaira Lucero, M. (2013). Immigration Policy and Entrepreneurship. International Migration, 52(2), 53-65.

57. Mandviwalla, M., \& Watson, R. (2014). Generating Capital from Social Media. MIS Quarterly Executive, 13(2), 97-113.

58. Meyer, D. (2014). Job creation, a mission impossible? The South African case. Mediterranean Journal of Social Sciences, 5(16), 65.

59. Nahapiet, J., \& Ghoshal, S. (1998). Social capital, intellectual capital, and the organisational advantage. Academy of management review, 23(2), 242-266.

60. Ndofor, H., \& Priem, R. (2011). Immigrant entrepreneurs, the ethnic enclave strategy, and venture performance. Journal of Management, 37(3), 790-818.

61. Nee, V., \& Sanders, J. (2001). Understanding the diversity of immigrant incorporation: a forms-of-capital model. Ethnic and Racial Studies, 24(3), 386-411.

62. Oliveira, C. (2008). The determinations of immigrant entrepreneurship strategies in Portugal. Migracoes, 3, 101-128.
63. Payne, G., Moore, C., Griffis, S., \& Autry, C. (2011). Multilevel challenges and opportunities in social capital research. Journal of Management, 37(2), 491-520.

64. Radipere, N. (2012). An analysis of local and immigrant entrepreneurship in South African small enterprise sector (Gauteng province) (Doctoral Thesis). University of South Africa.

65. Raijman, R., \& Tienda, M. (1999). Immigrants' socioeconomic progress post-1965: Forging mobility or survival? In C. Hirschman, P. Kasinitz \& J. DeWind (Eds.), The Handbook of International Migration: The American Experience (pp. 175211). New York: Russell Sage Foundation.

66. Rogerson, C. (1997). International migration, immigrant entrepreneur and South Africa's small enterprise economy (Southern Africa Migrants Projects: Migration Policy Series, 3). Institute for Democracy in South Africa.

67. Sahin, M., Nijkamp, P., \& Levent, T. (2006). Migrant Entrepreneurship from the perspective of Cultural Diversity (Series Research Memoranda, No. 6). VU University, Amsterdam.

68. Sanders, J. M., \& Nee, V. (1996). Immigrant self-employment: The family as social capital and the value of human capital. American Sociological Review, 61(2), 231-249.

69. Schuetze, H., \& Antecol, H. (2007). Immigration Entrepreneurship and the Venture Start-up Process. In S. Parker (Ed.), The Life Cycle of Entrepreneurial Ventures. International Handbook Series on Entrepreneurship (p. 3). New York.

70. Sequeira, J., \& Rasheed, A. (2006). Start-up and Growth of Immigrant Small Businesses: The Impact of Social and Human Capital. Journal of Development Entrepreneurship, 11(4), 357-375.

71. Setati, M., \& Adler, J. (2000). Between languages and discourses: Language practices in primary multilingual mathematics classrooms in South Africa. Educational Studies in Mathematics, 43(3), 243-269.
72. Spinelli, S., \& Adams, R. (2012). New Venture Creation. Entrepreneurship for the $21^{\text {st }}$ Century (9th ed.). McGraw-Hill International Edition.

73. Statistics South Africa (2017, June). Consumer Price Index (CPI). Retrieved from http://www.statssa. gov.za/?p=10658 (accessed on June 19, 2017)

74. Tengeh, R. (2013). A business survival framework for African immigrant-owned businesses in the Cape Town Metropolitan area of South Africa. Mediterranean Journal of Social Science, 4(13), 247-260

75. Timberg, C. (2005). Refugees with hopes, skills find opportunities in South Africa. Washington Post, Foreign Services, A21.

76. Turkina, E., \& Thai, M. (2013). Social capital, networks, trust and immigrant entrepreneurship: a cross-country analysis. Journal of Enterprising Communities: People and Places in the Global Economy, $7(2), 108-124$.

77. Uzzi, B. (1997). Social structure and competition in interfirm networks: The paradox of embeddedness. Administrative Science Quarterly, 41(1), 35-67.

78. Watt, S., Simpson, C., McKillop, C., \& Nunn, V. (2002). Electronic course surveys: does automating feedback and reporting give better results? Assessment \& Evaluation in Higher Education, 27(4), 325337.

79. Zhou, M. (2007). Non-economic effects of Ethnic Entrepreneurship. In L. P. Dana (Ed.), Handbook of Research on Ethnic Minority Entrepreneurship. Edward Elgar, Northampton. 